\title{
PERLINDUNGAN HUKUM BAGI PARA PIHAK DALAM PEMBATALAN \\ PERJANJIAN JUAL BELI AKIBAT PERBUATAN MELAWAN HUKUM (CONTOH KASUS PUTUSAN MAHKAMAH AGUNG NOMOR 523 K/PDT/2017)
}

\author{
Angelica Natalie \\ (Mahasiswa Program S1 Fakultas Hukum Universitas Tarumanagara) \\ (28angelicanatalie@gmail.com)
}

\section{Dr. S. Atalim, S.H., M.H.}

(Dosen Fakultas Hukum Universitas Tarumanagara. Meraih Sarjana Hukum pada Fakultas Hukum Universitas Indonesia, Magister Hukum pada Fakultas Hukum Universitas Indonesia, Doktor (Dr.) pada Fakultas Hukum Universitas Parahyangan)

(st_atalim@yahoo.com)

\begin{abstract}
There are differences between contract and tort laws, which lies in the issue of consent. Because in a contract, the parties need to enter an agreement knowingly and without being coerced for the contract to be valid, that means the parties are aware of the risk entailed and the outcome of the contract. Damages in contract claim usually happened because of mistakes or misunderstandings between the parties. On the other hand, the interaction in a tort is never based on consent. Torts generally involve an intrusion by one party into the privacy, health, profit and safety of the victim. In fact, if the victim consents to the tortious conduct, it can serve as a defense that will prevent them from recovering damages. However in Indonesia court of law, the judges accept to restore damages and even the cancellation of the agreement or contract between the parties due to tort, the judges in many cases have shown that they accepted tort as a reason for cancellation of an agreement, this provides legal protection for the parties in cancellation of the sale and purchase agreement due to tort, even if it's not ensured that all contract cases can be solved this way or if it's even lawfully right, as there is an important differences between tort and breach in contract, the case example can be seen on Supreme Court Verdict Number 523 K/PDT/2017 which verdicted undue influence causing a tort and cancelled the sale and purchase agreement between the parties.
\end{abstract}

Keywords: Legal Protection, Tort, Cancellation Of Sale and Purchase Agreement, Undue Influence. 


\section{PENDAHULUAN}

\section{A. Latar Belakang}

Indonesia adalah negara yang menempatkan hukum pada tempat yang tinggi dan sangat menjunjung tinggi hukum, hal ini dapat terlihat dari Undang-Undang Dasar Negara Republik Indonesia Tahun 1945 (yang selanjutnya disebut UUD NRI 1945) dalam Pasal 1 Ayat (3) yang menyatakan bahwa Negara Indonesia adalah negara hukum. Dengan dinyatakannya Indonesia sebagai negara hukum maka segala kegiatan masyarakat di Indonesia baik dari segi ekonomi, sosial dan budaya diatur melalui norma hukum. Manusia sendiri sebagai makhluk sosial memerlukan aturan hukum yang mengatur tingkah laku manusia agar tercipta keharmonisan sosial. ${ }^{1)}$ Hal tersebut menyebabkan lahirnya tindakan hukum atau hubungan hukum antara manusia dengan manusia lainnya.

Hubungan hukum itu sendiri merupakan bentuk hubungan yang diatur oleh hukum dimana hubungan hukum antar subjek hukum bisa terjadi antara seorang dengan seorang lainnya. ${ }^{2)}$ Subjek hukum sebagai pihak yang memiliki hak-hak dan juga kewajiban-kewajiban, baik manusia, badan hukum, maupun jabatan memiliki hak untuk melakukan tindakan hukum berdasarkan kemampuan atau kewenangan yang dimilikinya. Dalam pergaulan di tengah masyarakat, banyak terjadi hubungan hukum yang muncul sebagai akibat adanya tindakan-tindakan hukum dari subjek hukum itu. ${ }^{3)}$ Hubungan hukum yang dilakukan antar manusia tersebut salah satunya adalah dalam bentuk perjanjian. Perjanjian itu sendiri merupakan perbuatan hukum yang menimbulkan akibat hukum yang merupakan

\footnotetext{
${ }^{1)}$ Peter Mahmud Marzuki, Pengantar Ilmu Hukum Edisi Revisi, (Jakarta: Prenadamedia Group, 2008), hal.124.

${ }^{2)}$ Ibid., hal.216.

${ }^{3)}$ Ridwan H.R., Hukum Administrasi Negara, Cetakan ke-13, (Jakarta: PT. RajaGrafindo Persada, 2017), hal.265.
} 
tujuan dari para pihak. ${ }^{4)}$ Menurut Subekti perjanjian adalah suatu peristiwa dimana seseorang berjanji kepada orang lain atau dimana dua orang itu saling berjanji untuk melaksanakan suatu hal. ${ }^{5)}$

Perjanjian itu sendiri harus memenuhi syarat-syarat yang merupakan syarat sahnya perjanjian, yaitu kata sepakat, kecakapan, hal tertentu dan suatu sebab yang halal, sebagaimana ditentukan dalam Pasal 1320 KUH Perdata. Dengan memenuhi keempat syarat perjanjian, maka suatu perjanjian dianggap sah dan menjadi mengikat secara hukum atau berlaku sebagai undang-undang bagi para pihak yang membuatnya. ${ }^{6}$ Salah satu bentuk perjanjian yang paling sering ditemui di dalam kehidupan sehari-hari adalah perjanjian jual beli. Jual beli adalah suatu perjanjian dimana salah satu pihak berjanji kepada pihak lain untuk menyerahkan hak milik yang ia miliki atas suatu barang, sedang pihak yang lain (si pembeli) berjanji kepada pihak penjual untuk membayar harga yang terdiri atas sejumlah uang sebagai imbalan atau pembayaran dari perolehan hak milik yang ia akan terima dari pihak penjual tersebut. ${ }^{7)}$

Tetapi meskipun demikian perjanjian yang sedang berlangsung sewaktuwaktu dapat dibatalkan berdasarkan 3 (tiga) alasan untuk pembatalan perjanjian yang diatur dalam Pasal 1321 KUH Perdata. Ketiga alasan pembatalan perjanjian terdiri dari: ${ }^{8)}$ yang pertama adalah kekhilafan/kesesatan (dwaling) (Pasal 1322 KUH Perdata), yang kedua adalah paksaan (dwang/bedreiging) (Pasal 1323 sampai dengan Pasal 1327 KUH Perdata) dan yang ketiga adalah penipuan

\footnotetext{
4) Herlien Budiono, Ajaran Umum Hukum Perjanjian dan Penerapannya di Bidang Kenotariatan, Cetakan ke-4, (Bandung: PT. Citra Aditya Bakti, 2014), hal.3.

${ }^{5)}$ R. Subekti, Hukum Perjanjian, Cetakan ke-13, (Jakarta: PT. Intermasa, 1991), hal.1.

${ }^{6}$ Suharnoko, Hukum Perjanjian Teori dan Analisis Kasus Edisi Kedua, Cetakan ke-9, (Jakarta: Prenadamedia Group, 2015), hal.1.

${ }^{7)}$ R. Subekti, Aneka Perjanjian, Cetakan ke-9, (Bandung: PT. Citra Aditya Bakti, 1992), hal.1.

${ }^{8)}$ Rendy Saputra, Kedudukan Penyalahgunaan Keadaan (Misbruik Van Omstandigheden) Dalam Hukum Perjanjian Indonesia, Cetakan ke-1, (Yogyakarta: Gadjah Mada University Press, 2016), hal.7.
} 
(bedrog) (Pasal 1328 KUH Perdata). Banyak pihak saat ini menyebutkan bahwa kesesatan atau kehilafan (dwaling), paksaan (dwang atau bedreiging) dan penipuan (bedrog) sebagaimana dinyatakan dalam Pasal 1321 KUH Perdata sebagai cacat kehendak dalam pembentukan kata sepakat pada suatu perjanjian. ${ }^{9}{ }^{9}$ Cacat kehendak (defect of consent) adalah kecacatan dalam pembentukan kata sepakat dalam suatu kontrak atau perjanjian. Apabila kesepakatan mengandung cacat kehendak, memang tampak adanya kata sepakat, tetapi kata sepakat itu dibentuk tidak berdasarkan kehendak bebas. ${ }^{10)}$ Dalam pembatalan perjanjian, dikenal juga istilah wanprestasi, dimana wanprestasi adalah kondisi salah satu pihak tidak memenuhi perjanjian yang sudah disepakati antara mereka. Wanprestasi sendiri terjadi karena adanya suatu kelalaian, kesalahan maupun kesengajaan dari salah satu pihak sehingga tidak dipenuhinya suatu prestasi dalam perjanjian tersebut. ${ }^{11}$ ) Salah satu konsekuensi dari dilakukannya wanprestasi ini adalah pembatalan perjanjian itu sendiri, diluar dari konsekuensi pihak yang melakukan wanprestasi diwajibkan untuk mengganti kerugian yang diderita oleh pihak yang dalam perjanjian tidak dipenuhi haknya ataupun melakukan kewajiban yang seharusnya dipenuhi dengan segera. Wanprestasi diatur dalam Pasal 1234 KUH Perdata yang menyatakan "Penggantian biaya, kerugian dan bunga karena tak dipenuhinya suatu perikatan mulai diwajibkan, bila debitur, walaupun telah dinyatakan lalai, tetap Ialai untuk memenuhi perikatan itu, atau jika sesuatu yang harus diberikan atau dilakukannya hanya dapat diberikan atau dilakukannya dalam waktu yang melampaui waktu yang telah ditentukan”. Di Indonesia suatu pembatalan perjanjian ternyata juga dapat terjadi jika ada perbuatan melawan hukum, perbuatan melawan hukum yang

\footnotetext{
${ }^{9)}$ Ibid.

${ }^{10)}$ Ibid., hal.6.

11) Yahman, Karakteristik Wanprestasi dan Tindak Pidana Penipuan Yang Lahir Dari Hubungan Kontraktual, Cetakan ke-3, (Jakarta: Prenadamedia Group, 2016), hal.83.
} 
penulis maksud dalam konsep ini termasuk perbuatan melawan hukum di bidang perdata. Perbuatan melawan hukum diatur dalam Pasal 1365 KUH Perdata yang menyatakan bahwa "Tiap perbuatan yang melanggar hukum dan membawa kerugian kepada orang lain, mewajibkan orang yang menimbulkan kerugian itu karena kesalahannya untuk menggantikan kerugian tersebut". Dalam proses pengadilan di Indonesia, banyak kasus di bidang perdata terutama di bidang perjanjian yang menerapkan perbuatan melawan hukum sebagai dasar gugatan agar bisa diminta pembatalan perjanjian serta ganti kerugian yang diderita oleh korban yang mengalami perbuatan melawan hukum.

Berkaitan dengan hal itu seiring dengan perkembangan hukum perdata dalam praktik peradilan dikenal pula bentuk faktor penyebab terjadinya cacat kehendak yang tidak diatur dalam Pasal 1321 KUH Perdata yaitu penyalahgunaan keadaan (misbruik van omstandigheden atau undue influence). ${ }^{12)}$ Yang dimana dikenal sebagai salah satu bentuk cacat kehendak yang dapat menjadi alasan pembatalan perjanjian dan ternyata dikaitkan erat sebagai perbuatan melawan hukum seperti yang bisa dilihat dalam contoh kasus yang akan penulis angkat dalam penulisan ini. Penyalahgunaan keadaan ini sendiri merupakan hasil dari penemuan hukum, dimana hakim menggali kaedah-kaedah hukum yang ada demi menegakkan keadilan. Tetapi ajaran yang berkaitan mengenai penyalahgunaan keadaan merupakan hal yang sebenarnya masih relatif baru di Indonesia sehingga pada kenyataannya penerapannya di bidang peradilan masih memiliki sejumlah permasalahan, salah satunya menyangkut keberadaan ajaran tersebut, karena penyalahgunaan keadaan ini memang belum diatur dalam KUH Perdata. ${ }^{13)}$ Selain itu, masalah lain yang timbul juga berkaitan dengan standar untuk menentukan adanya penyalahgunaan keadaan tersebut. ${ }^{14)} \mathrm{Hal}$ ini

\footnotetext{
${ }^{12)}$ Rendy, Op.Cit., hal.7.

${ }^{13)}$ Ibid., hal.10.

${ }^{14)}$ Rendy, Loc.cit.
} 
tentunya dapat pula menimbulkan ketidakpastian atas perlindungan hukum bagi para pihak apabila terjadi pembatalan perjanjian akibat penyalahgunaan keadaan, karena pada kenyatannya banyak gugatan mengenai tindakan penyalahgunaan keadaan ini yang dikaitkan dengan perbuatan melawan hukum.

Salah satu contoh kasus yang mencerminkan adanya unsur tersebut dalam praktik peradilan yang berkaitan dengan pembatalan perjanjian jual beli adalah kasus dari Pengadilan Negeri Jakarta Selatan dengan putusan Nomor 305/Pdt.G/2014/PN.Jkt.Sel yang dikuatkan dengan Putusan Mahkamah Agung Nomor 523 K/Pdt/2017. Kasus ini terjadi antara Ichwan Susilo sebagai pemilik atas suatu tanah dan bangunan (penjual) dengan Jimmy M.P. Johanes yang membeli tanah tersebut (pembeli) serta Ronald Soetrisno sebagai pembeli tanah dari Jimmy. Awalnya Ichwan melakukan perjanjian jual beli dengan Jimmy yang berprofesi sebagai seorang advokat dengan menandatangani Perjanjian Pengikatan Jual Beli (yang selanjutnya disebut PPJB) nomor PPJB 01/2010 dan Akta Surat Kuasa No. 02, tertanggal 14 Oktober 2010. Di sini Ichwan menggugat Jimmy dengan dalil bahwa pihak tergugat telah melakukan penyalahgunaan keadaan dimana tergugat memanfaatkan kondisi penggugat yang sedang memiliki masalah hukum sehingga terjadilah perjanjian jual beli untuk mengalihkan aset berupa tanah beserta bangunan rumah yang berada di atasnya dimana tergugat pada awalnya mengatakan bahwa tindakan hukum inilah yang tepat untuk melindungi aset milik penggugat dengan janji aset itu akan dikembalikan setelah permasalahan hukum yang dialami penggugat selesai.

Tetapi tergugat tidak mengembalikan aset tersebut dan menjualnya kepada pihak lain yaitu Ronald. Penggugat mendalilkan perbuatan penyalahgunaan keadaan itu termasuk ke dalam perbuatan melawan hukum. Hakim memutuskan bahwa tergugat harus mengganti kerugian yang dialami oleh penggugat dan aset tetap sebagai kepemilikan Ronald. Maka tergugat dinyatakan telah melakukan perbuatan penyalahgunaan keadaan kepada penggugat dan dianggap sudah melakukan perbuatan melawan hukum. Dengan adanya putusan hakim tersebut 
menunjukkan bahwa hukum Indonesia telah mengikuti perkembangan hukum perjanjian dengan diterapkannya pembatalan perjanjian jual beli akibat perbuatan melawan hukum yang timbul karena adanya penyalahgunaan keadaan.

Oleh karena itu penulis tertarik untuk meneliti lebih lanjut tentang perlindungan hukum bagi para pihak apabila terjadi pembatalan perjanjian jual beli akibat perbuatan melawan hukum. Karena pada dasarnya perbuatan melawan hukum tidak terjadi dengan dasar tidak dipenuhinya suatu kontrak atau perjanjian, berbeda dengan wanprestasi, melainkan perbuatan melawan hukum lebih melihat kepada tindakan kesalahan yang dibuat oleh salah satu pihak yang merugikan orang lain, hal ini dapat menimbulkan pertanyaan serta ketidakpastian dalam perlindungan hukum bagi para pihak ketika terjadi pembatalan perjanjian jual beli karena pada umumnya hal-hal yang berkaitan dengan pelanggaran kontrak atau perjanjian yang dilakukan salah satu pihak sebagai bentuk wanprestasi dan bukanlah perbuatan melawan hukum, dan pada kenyataannya KUH Perdata juga belum mengatur secara khusus mengenai penyalahgunaan keadaan yang disebut sebagai perbuatan melawan hukum itu. Namun, pengaturan tentang hal ini dapat ditemukan dalam yurisprudensi.

Berdasarkan latar belakang yang telah ditulis di atas maka Penulis tertarik mengadakan penelitian lebih lanjut yang dituangkan ke dalam suatu penulisan dengan judul "Perlindungan Hukum Bagi Para Pihak Dalam Pembatalan Perjanjian Jual Beli Akibat Perbuatan Melawan Hukum (Contoh Kasus Putusan Mahkamah Agung Nomor 523 K/Pdt/2017)”.

\section{B. Perumusan Masalah}

Bertolak dari latar belakang di atas, maka penulis ingin merumuskan masalah sebagai berikut:

Bagaimana perlindungan hukum bagi para pihak dalam pembatalan perjanjian jual beli akibat perbuatan melawan hukum (contoh kasus putusan Mahkamah Agung Nomor 523 K/Pdt/2017)? 


\section{Metode Penelitian}

Jenis penelitian yang penulis gunakan untuk penulisan ini adalah dengan metode penelitian hukum normatif, dimana metode penelitian dilakukan dengan melakukan penelitian kepustakaan. Sementara berkaitan dengan pengumpulan data untuk menjawab permasalahan mengenai perlindungan hukum bagi para pihak dalam pembatalan perjanjian jual beli akibat perbuatan melawan hukum maka alat pengumpulan data yang digunakan penulis adalah studi dokumen atau penelusuran literatur dan wawancara. Teknik analisis data yang digunakan penulis adalah dengan analisis normatif kualitatif bahwa peneliti dalam menganalisis masalah mengenai perlindungan hukum bagi para pihak dalam pembatalan perjanjian jual beli akibat perbuatan melawan hukum berkeinginan untuk memberikan pemaparan atas hasil penelitian yang dilakukannya melalui bentuk berupa penguraian. ${ }^{15)}$

\section{PEMBAHASAN}

\section{A. Kronologi Kasus}

Pada tanggal 14 Oktober 2010, antara Penggugat dan Tergugat I telah menandatangani Akta Perjanjian Pengikatan Jual Beli dan Akta Surat Kuasa yang merupakan perjanjian jual beli untuk tanah beserta bangunan yang terletak di Jalan Rambai III Nomor 3, Kelurahan Kramat Pela, Kecamatan Kebayoran Baru, Jakarta Selatan dengan luas $336 \mathrm{~m}^{2}$ (tiga ratus tiga puluh enam meter persegi). Setelah itu pada tahun 2011, tanpa sepengetahuan Penjual (Ichwan Susilo), pihak Pembeli (Jimmy M.P. Johanes) mendaftarkan perubahan kepemilikan berdasarkan Akta Jual Beli Nomor 2 Tahun 2011. Setelah mengetahui bahwa tanah beserta bangunan tersebut ternyata telah dijual kepada pihak ketiga yaitu Ronald Soetrisno, dimana diketahui Ronald pernah

${ }^{15)}$ Mukti Fajar Nur Dewata dan Yulianto Achmad, Dualisme Penelitian Hukum Normatif \& Empiris, Cetakan Ke-4, (Yogyakarta: Pustaka Pelajar, 2017), Hal.183. 
menjaminkan objek sengketa tersebut. Obyek gugatan di dalam putusan ini merupakan tanah beserta bangunan yang terletak di Jalan Rambai III Nomor 3, Kelurahan Kramat Pela, Kecamatan Kebayoran Baru, Jakarta Selatan dengan luas $336 \mathrm{~m}^{2}$ (tiga ratus tiga puluh enam meter persegi) dengan Sertipikat Hak Milik No mor 823/Kramat Pela, tertanggal 1 Oktober 1998, dengan Salinan Gambar Situasi Nomor 8/635/1977, tertanggal 4 Juni 1977, dan Nomor Induk Bangunan 09.04.05.05.00109 (untuk selanjutnya disebut sebagai “SHM 823”).

\section{B. Dasar Gugatan}

Pihak Penggugat menuntut kembali tanah beserta bangunan yang sudah dijual kepada pihak ketiga oleh pihak Tergugat I dengan dalil bahwa perjanjian jual beli yang dilakukan antara Ichwan Susilo dengan Jimmy M.P. Yohanes memiliki unsur Penyalahgunaan Keadaan (Misbruik Van Omstandigheden) serta pengalihan hak milik objek sengketa dari Penggugat ke Tergugat I dilakukan tanpa sepengetahuan Penggugat dan sudah sepatutnya dibatalkan. Awalnya Penggugat yang pada saat itu sedang mengalami masalah hukum, meminta bantuan Tergugat I yang berprofesi sebagai seorang Advokat untuk menyelesaikan masalah hukum yang sedang dialaminya, akhirnya antara kedua belah pihak bersepakat melakukan perjanjian jual beli dimana Penggugat menyetujui perjanjian ini dengan dasar kepercayaan bahwa perjanjian jual beli ini dilakukan karena dapat melindungi aset milik Penggugat. Penggugat merasa Tergugat I sudah melakukan perbuatan melawan hukum dengan melakukan tindakan secara sepihak dan tanpa sepengetahuan Penggugat mengambil alih kepemilikan tanah beserta bangunan tersebut lalu menjualnya juga kepada pihak ketiga. Sedangkan pihak Tergugat I menyatakan bahwa perjanjian jual beli yang dilakukan sudah berlangsung secara sah dan pembayaran juga sudah dilunasi serta tidak ada unsur Penyalahgunaan Keadaan yang dilakukan oleh Tergugat I.

\section{Teori Perbuatan Melawan Hukum}


Perbuatan Melawan Hukum yang dimaksud dalam penulisan ini adalah merupakan tindakan perbuatan melawan hukum yang berkaitan dengan bidang keperdataan, dimana dalam prakteknya sudah banyak gugatan perdata yang menggunakan perbuatan melawan hukum sebagai dasar gugatannya, disamping wanprestasi. ${ }^{16)}$ Ilmu Hukum sendiri mengenal bahwa ada tiga kategori yang disebut sebagai perbuatan melawan hukum, yaitu: Perbuatan melawan hukum karena kesengajaan, perbuatan melawan hukum tanpa kesalahan (tanpa unsur kesengajaan maupun kelalaian); dan perbuatan melawan hukum karena kelalaian. Sesuai dengan ketentuan yang tercantum dalam Pasal 1365 KUH Perdata, maka perbuatan melawan hukum harus memiliki unsur-unsur berikut: ${ }^{17)}$

a. Ada suatu perbuatan

Suatu perbuatan melawan hukum tentunya berawal dengan ada perbuatan dari pelaku yang pada umumnya perbuatan itu merupakan tindakan pelaku yang baik berbuat sesuatu maupun tidak berbuat sesuatu (dalam arti pasif). Yang dimaksudkan dengan tidak berbuat sesuatu adalah kondisi dimana seseorang tidak melakukan sesuatu yang sudah seharusnya ia lakukan karena dia mempunyai kewajiban hukum dari hukum yang berlaku (dan hal ini berbeda dari kewajiban hukum yang timbul dari perjanjian maka bukan kewajiban hukum karena perjanjian). Dalam perbuatan melawan hukum tidak dikenal adanya unsur "persetujuan atau kata sepakat" dan tidak ada unsur "causa yang diperbolehkan" sebagaimana yang ada dalam kontrak.

b. Perbuatan tersebut melawan hukum

Semua dimulai pada tahun 1919 dimana unsur melawan hukum ini diartikan secara luas dan meliputi hal-hal berikut: perbuatan yang

\footnotetext{
16) Munir Fuady, Perbuatan Melawan Hukum Pendekatan Kontemporer, Cetakan ke-5, (Jakarta: PT. Citra Aditya Bakti, 2017), hal.1.

${ }^{17)}$ Munir Fuady, Op.Cit., hal.10-13.
} 
melanggar undang-undang yang berlaku, yang melanggar hak orang lain yang dijamin oleh hukum, perbuatan yang bertentangan dengan kewajiban hukum si pelaku, perbuatan yang bertentangan dengan kesusilaan, perbuatan yang bertentangan dengan sikap yang baik dalam bermasyarakat untuk memperhatikan kepentingan orang lain.

c. Adanya kesalahan dari pihak pelaku

Wajib adanya unsur kesalahan yang dilakukan pelaku agar dapat dikenakan Pasal 1365 KUH Perdata mengenai perbuatan melawan hukum tersebut. Unsur kesalahan yang dimaksud harus memenuhi unsur-unsur sebagai berikut: adanya unsur kesengajaan, atau ada unsur kelalaian, dan tidak ada alasan pembenar atau alasan pemaaf yang dapat ditemukan pada pelaku, seperti keadaan memaksa (overmacht), membela diri, tidak waras dan lain-lain.

d. Adanya kerugian bagi korban

Kerugian berbeda dengan kerugian dalam wanprestasi yang hanya mengenal kerugian materil, maka kerugian karena perbuatan melawan hukum disamping kerugian materil dalam yurisprudensi juga mengakui adanya konsep kerugian immateril yang akan dinilai juga dengan uang.

e. Adanya hubungan kausal antara perbuatan dengan kerugian

Hubungan kausal antara perbuatan yang dilakukan dengan kerugian yang terjadi adalah syarat perbuatan melawan hukum. Untuk hal ini terdapat dua macam teori, yaitu teori hubungan faktual dan teori penyebab kira-kira. Dimana hubungan sebab akibat secara faktual hanyalah merupakan masalah fakta atau apa yang secara faktual sudah terjadi. Sementara untuk penyebab kira-kira dibentuk agar lebih tercapai kepastian hukum dan hukum yang lebih adil, dimana terkadang hal ini menimbulkan pertentangan pendapat. ${ }^{18)}$

\footnotetext{
${ }^{18)}$ Munir Fuady, Op.Cit., hal.14.
} 
Ganti rugi sendiri dalam perbuatan melawan hukum itu ada tiga yang dikenal dan telah diterapkan secara nyata, yaitu sebagai berikut: ${ }^{19)}$ yang pertama adalah ganti rugi nominal, dimana jika ada perbuatan melawan hukum yang serius, seperti perbuatan pelaku perbuatan melawan hukum yang ternyata mengandung unsur kesengajaan tetapi tidak menimbulkan adanya kerugian nyata bagi korban, maka korban tersebut bisa diberi sejumlah uang tertentu yang merupakan ganti kerugian dari si pelaku dan hal ini dilakukan sesuai dengan rasa keadilan, maka tidak menghitung secara pasti sebenarnya berapa kerugian yang diderita korban melainkan berpatokan pada keadilan yang dirasa tepat, yang kedua adalah ganti rugi kompensasi dimana ganti rugi yang diberikan masih berupa pembayaran tetapi pembayaran tersebut benar-benar jumlahnya secara pasti merupakan kerugian nyata yang diderita oleh korban itu sendiri, ganti rugi ini juga disebut sebagai ganti rugi aktual, dan yang terakhir adalah ganti rugi penghukuman dimana ganti rugi ini merupakan suatu ganti rugi yang dalam jumlah besar melebihi jumlah kerugian yang sebenarnya, besar jumlah ganti rugi ini dimaksudkan sebagai hukuman bagi pihak pelaku. Biasanya diterapkan ganti rugi penghukuman ini terhadap kasus-kasus kesengajaan yang berat.

Ganti rugi dalam konsep perbuatan melawan hukum dan dalam ganti rugi karena kontrak berbeda, biasanya dalam perbuatan melawan hukum sistem ganti rugi akan lebih keras daripada ganti rugi dalam sistem kontrak. Hal ini disebabkan karena jika para pihak telah memiliki keberanian untuk masuk dalam suatu perjanjian dan menandatangani kontrak tersebut, maka pihak tersebut sedikit banyaknya sudah berani mengambil risiko-risiko tertentu, termasuk risiko kerugian yang terbit akibat kontrak tersebut. Sehingga ganti rugi yang diberlakukan tidak terlalu keras, berbeda dengan korban dari perbuatan melawan hukum, yang sama sekali tidak mengetahui bahwa akan ada risiko yang dideritanya, karena korban tidak pernah terpikir dan tidak siap menerima risiko

\footnotetext{
${ }^{19)}$ Munir Fuady, Op.Cit., hal.134-135.
} 
yang datang tiba-tiba tersebut. Pihak tersebut harus dilindungi sehingga ganti rugi bagi perbuatan melawan hukum lebih luas dan lebih tegas berlakunya. ${ }^{20)}$

\section{Data Hasil Wawancara}

Penulis melakukan wawancara dengan beberapa narasumber yang akan digunakan sebagai referensi untuk menjawab permasalahan dalam penulisan ini. Berikut hasil wawancara yang dilakukan narasumber dengan beberapa ahli.

\section{Abdul Gani Abdullah}

Untuk lebih mengetahui mengenai Perbuatan Melawan Hukum yang berkaitan dengan Penyalahgunaan Keadaan (Misbruik Van Omstandigheden) dari segi pandangan hakim, penulis mewawancarai Abdul Gani Abdullah dimana beliau pernah menjabat sebagai Hakim Agung Republik Indonesia, beliau juga mengajar pada beberapa pendidikan dasar dan menengah dan perguruan tinggi, menjadi pegawai pada Badan Peradilan Agama, pejabat eselon 1 pada Depertemen Hukum dan Hak Asasi Manusia.

Beliau berpendapat bahwa dalam perlindungan hukum apabila adanya penyalahgunaan keadaan sama-sama melindungi semua pihak jika ada penyalahgunaan keadaan, tidak bisa salah satu pihak lebih kuat daripada yang lain. Jika ada ketidakseimbangan antara para pihak dalam perjanjian, dan merugikan hak dari pihak yang lebih lemah, hal tersebut seharusnya tidak boleh terjadi, sehingga dalam pengadilan harus mempertimbangkan kerugian dari pihak yang lebih lemah daripada pihak yang lebih kuat. Hakim tidak boleh menyatakan suatu kasus sebagai penyalahgunaan keadaan saja, sebab karena jika belum ada hukumnya untuk mengadili suatu kasus, hakim harus mencari hukumnya, karena penyalahgunaan keadaan belum diatur dalam perundang-undangan di Indonesia, karena itu hakim bisa mengaitkan dengan hal-hal lain yang sudah diatur dalam perundang-undangan di Indonesia dan berpihak pada pihak yang dirugikan. Hakim harus mencari

\footnotetext{
${ }^{20)}$ Munir Fuady, Op.Cit., hal.135-136.
} 
suatu hukum yang menempatkan para pihak dalam posisi yang seimbang, meskipun dalam perjanjian pada kenyataannya para pihak tidak seimbang tetapi dalam pengadilan harus seimbang dan sama posisi serta kekuatan hukumnya. Karena itu hakim harus menemukan hukum yang ada keseimbangan antara kedua belah pihak yang bersengketa ataupun dalam perjanjian, jika dalam perjanjian ternyata para pihak tidak seimbang, hakim harus meluruskan hal tersebut. Hakim di pengadilan tingkat pertama dan kedua mencari kepastian hukum (legal certainty) yang harus ada, dicari oleh hakim pasal tersebut ada dimana, dan akhirnya hakim di pengadilan tingkat kasasi bisa memeriksa lalu memutuskan bahwa pengadilan tingkat pertama dan kedua telah salah menerapkan hukum lalu pada saat itulah hakim mencari hukum, karena hakim di tingkat kasasi memiliki kewenangan untuk menciptakan hukum (rechtsschepping) dan bentuk nyatanya adalah melalui yurisprudensi.

Jika penyalahgunaan keadaan dialihkan menjadi perbuatan melawan hukum, maka bisa diterapkan karena ada pihak yang tidak seimbang dalam suatu perjanjian, hakim dapat menerapkan unsur-unsur tersebut apabila memang bisa terbukti dalam pengadilan. Apalagi dalam kasus yang diangkat penulis, para pihak sudah mengetahui bahwa tindakan yang ia lakukan sebenarnya tidak boleh dan tidak sesuai dengan kesepakatan yang sudah disepakati, perbuatan melawan hukum akibat penyalahgunaan keadaan dapat menjadi alasan untuk pembatalan perjanjian jual beli, karena ada salah satu pihak yang dirugikan dan unsur pembuktiannya sudah terbukti bahwa memang ada penyalahgunaan keadaan atau perbuatan melawan hukum yang dilakukan oleh salah satu pihak dan merugikan orang lain, pada akhirnya hakim harus menyeimbangkan posisi para pihak yang tidak seimbang tersebut. Untuk menerapkan doktrin penyalahgunaan keadaan ini hakim bisa mencari hukum dengan menerapkan hukum-hukum yang lain. 
2. Munir Fuady

Penulis mewawancarai Munir Fuady dimana beliau memiliki profesi sebagai konsultan hukum perusahaan dan juga berprofesi sebagai advokat senior di Jakarta. Beliau juga merupakan dosen di berbagai universitas dimana salah satunya adalah Universitas Tarumanagara dan beliau juga sering dipanggil untuk menjadi saksi ahli di berbagai forum pengadilan dan arbitrase, beliau juga sering dipanggil sebagai saksi ahli dalam kasus yang berkaitan dengan perbuatan melawan hukum dan penyalahgunaan keadaan. Beliau juga telah menulis ratusan artikel di berbagai koran, majalah, buletin ilmiah, dan telah menulis banyak buku tentang hukum, serta melakukan berbagai penelitian hukum. Salah satu buku beliau yang terkenal juga berjudul "Perbuatan Melawan Hukum (Pendekatan Kontemporer)" yang penulis gunakan sebagai salah satu sumber pustaka pada penelitian ini.

Beliau menerangkan Penyalahgunaan Keadaan (Misbruik Van Omstandigheden) sebagai Penyalahgunaan Keadaan suatu transaksi antara dua pihak yang dibuat dimana syarat-syarat formalitas terpenuhi, tetapi dilakukan dengan cara dimana salah satu pihak menyalahgunakan keadaan yang terjadi yang pada umumnya dimana salah satu pihak yang kuat dalam kekuasaannya memanipulasi keadaan yang ada atau memanipulasi pihak lain yang lebih lemah dan menimbulkan adanya transaksi berat sebelah. Penyalahgunan Keadaan bisa dijadikan sebagai salah satu alasan pembatalan perjanjian, tetapi beliau berpendapat pada saat ini memang agak lemah karena sebenarnya belum diatur dalam peraturan perundang-undangan di Indonesia. Dalam sistem hukum Indonesia dan umumnya sistem hukum Eropa Kontinental tidak mengenal Penyalahgunaan Keadaan, alasan ini awalnya ada pada sistem hukum Common Law, tetapi karena banyak ketidakadilan yang terjadi beberapa sistem hukum mencoba memasukkan paham tersebut, contohnya Belanda yang sudah memasukkan Penyalahgunaan Keadaan dalam Kitab Undang-Undang Perdata Belanda 
Baru (Niew Burgerlijk Wetboek). Jadi pada Anglo Saxon mengenal Undue Influence atau yang disebut juga sebagai Penyalahgunaan Keadaan, dimana ada para pihak yang terpaksa melakukan perjanjian karena tidak seimbangnya kedudukan para pihak.

Penyalahgunaan Keadaan masih lemah karena belum diatur dalam undang-undang di Indonesia, maka jika salah satu pihak ingin membatalkan perjanjian sebaiknya mengaitkan juga ke salah satu alasan pembatalan perjanjian yang sudah diatur dalam KUH Perdata di Indonesia. Misalnya yang diatur dalam Pasal 1320 KUH Perdata, syarat sahnya perjanjian harus ada kata sepakat antara kedua belah pihak, tetapi kata sepakat antara kedua belah pihak ternyata lemah, bukan sepakat yang benar-benar sepakat dan terkesan semu, atau ternyata salah satu pihak tidak memiliki itikad baik dan bisa dikaitkan dalam pasal lain yang mengatur hal tersebut dalam KUH Perdata. Berbeda dengan negara yang sudah menerapkan doktrin Penyalahgunaan Keadaan dalam peraturan perundang-undangan mereka, tidak perlu lagi mengaitkan dengan alasan pembatalan perjanjian yang lain karena sudah ada diatur secara konkrit.

Di Indonesia sudah banyak kasus yang menggunakan Penyalahgunaan Keadaan dengan memakai Yurisprudensi dan pada awalnya juga ada kasus yang diselesaikan dengan menggunakan doktrin tersebut. Penyalahgunaan Keadaan jika dibandingkan dengan unsur cacat kehendak lain memiliki perbedaan yang signifikan karena dalam unsur Penyalahgunaan Keadaan harus ada pihak yang menyalahgunakan keadaan atau ada posisi para pihak yang tidak seimbang dan meskipun ada unsur-unsur perbuatan yang dilakukan salah satu pihak yang dapat dikategorikan sebagai unsur cacat kehendak lain seperti kekhilafan/kesesatan, paksaan atau penipuan tetapi Penyalahgunaan Keadaan dapat dikaitkan dengan Asas Itikad Baik, dimana perjanjian harus dilakukan dengan itikad baik. 
Dalam kasus yang diangkat diketahui pihak Penggugat melalui kuasa hukumnya mendalilkan bahwa Penyalahgunaan Keadaan yang dilakukan tersebut termasuk ke dalam Perbuatan Melawan Hukum, dimana dikaitkan dengan Pasal 1365 KUH Perdata, berkenaan dengan hal tersebut narasumber berpendapat bahwa dapat dikaitkan demikian antara Penyalahgunaan Keadaan dengan Perbuatan Melawan Hukum namun seharusnya lebih dikaitkan kepada Pasal 1320 KUH Perdata dan tidak perlu sampai dibawa ke dalam Perbuatan Melawan Hukum karena tanpa perlu dikaitkan dengan Perbuatan Melawan Hukum tetap dapat membatalkan perjanjian jual beli tersebut, tetapi belum tentu membatalkan perjanjian jual beli yang dilakukan oleh Tergugat II dan Tergugat III karena antara kedua belah pihak tersebut adanya penerapan Asas Itikad Baik pada Tergugat III.

Beliau juga berpendapat bahwa dalam sistem hukum di Indonesia untuk masalah dasar gugatan perjanjian yang dikenal ada dua yaitu Wanprestasi dan Perbuatan Melawan Hukum. Seharusnya dalam kaitan pembatalan perjanjian secara umum berkaitan dengan wanprestasi dan bukanlah perbuatan melawan hukum. Karena dalam proses perjanjian para pihak sudah sepakat untuk masuk dalam suatu perjanjian dengan mengetahui segala resikonya, berbeda dengan perbuatan melawan hukum dimana pihak yang menjadi korban tidak mengetahui bahwa ia akan mengalami kerugian. Perbuatan melawan hukum tetapi dimungkinkan dalam pengadilan di Indonesia untuk menjadi alasan pembatalan perjanjian, karena apabila memenuhi syarat-syarat perbuatan melawan hukum dalam Pasal 1365 KUH Perdata, maka dapat diterima gugatan tersebut. Pada umumnya juga banyak pihak lebih memilih untuk mengaitkan suatu masalah dalam perjanjian dengan perbuatan melawan hukum karena dalam unsur ganti kerugian biasanya lebih besar dibandingkan ganti rugi dalam perbuatan wanprestasi, serta di dalam wanprestasi belum tentu menuntut adanya kesalahan seperti pada perbuatan melawan hukum yang menuntut adanya suatu kesalahan 
sehingga tidak semua hal tercakup dalam wanprestasi yang menyebabkan banyak pihak yang membawa kasus-kasus perjanjian dalam perbuatan melawan hukum, bisa jadi dalam satu kasus bukan hanya satu dasar gugatan seperti perbuatan melawan hukum saja, bisa saja suatu kasus memenuhi unsur wanprestasi, malpraktek dan sebagainya. Tetapi condongnya para pihak pasti memilih unsur yang lebih bisa memberikan ganti rugi yang lebih besar, apalagi perbuatan melawan hukum bisa memberikan adanya ganti kerugian immateril yang hanya ada pada perbuatan melawan hukum, sedangkan wanprestasi tidak memberikan ganti kerugian immateril melainkan hanya materiil saja. Dalam pembuktian dalam gugatan dengan dasar perbuatan melawan hukum biasanya lebih sulit dan susah untuk menghubungkan perbuatan kesalahan tersebut dengan hal-hal lainnya seperti perjanjian, kalau untuk wanprestasi biasanya pembuktian lebih mudah karena jika seseorang melanggar suatu perjanjian sudah pasti harus mengganti kerugian tersebut.

\section{F. Perlindungan Hukum Bagi Para Pihak Dalam Pembatalan Perjanjian Jual Beli Akibat Perbuatan Melawan Hukum}

Seperti yang sudah dibahas dalam sebelumnya, diketahui bahwa perjanjian merupakan kesepakatan dan kesesuaian kehendak antara para pihak yang terikat melalui perjanjian tersebut. Dari ketentuan Pasal 1313 KUH Perdata dapat disimpulkan bahwa perjanjian mengikat para pihak dan kesepakatan yang tercapai dari kehendak para pihak yang menentukan terbentuknya perjanjian. Dalam prosesnya dapat terjadi pembatalan perjanjian apabila perjanjian tidak memenuhi syarat-syarat dalam Pasal 1320 KUH Perdata. Syarat-syarat itu berlaku bagi semua bentuk perjanjian, diantaranya adalah perjanjian jual beli. Jika suatu perjanjian tidak memiliki kata sepakat atau para pihak tidak cakap untuk membentuk perjanjian maka suatu perjanjian dapat dimintakan pembatalannya. Sementara jika suatu perjanjian tidak memenuhi syarat-syarat 
objektif yaitu suatu hal tertentu atau suatu sebab yang halal, maka suatu perjanjian menjadi batal demi hukum. Perjanjian yang sedang berlangsung juga sewaktu-waktu dapat dibatalkan berdasarkan 3 (tiga) alasan untuk pembatalan perjanjian yang diatur dalam Pasal 1321 KUH Perdata yang juga dikenal sebagai suatu cacat kehendak, yakni kecacatan dalam pembentukan kata sepakat dalam suatu kontrak atau perjanjian.

Pihak yang ingin membatalkan perjanjian jual beli dapat meminta kepada pengadilan untuk putusan pembatalan perjanjian oleh hakim. Hakim sebagai memiliki kewenangan untuk membatalkan perjanjian antara para pihak apabila memang terbukti perjanjian tersebut tidak memenuhi ketentuan yang berlaku atau apabila ada pihak yang tidak memenuhi kewajiban yang seharusnya ia penuhi sesuai dengan perjanjian yang disepakati oleh para pihak. Hukum di Indonesia sudah mengatur mengenai pembatalan perjanjian melalui beberapa peraturan perundang-undangan, terutama melalui Buku ke-III (tiga) KUH Perdata mengenai Perikatan. Tetapi dalam kehidupan bermasyarakat terjadi banyak masalah perdata berkaitan dengan perjanjian yang ternyata tidak semuanya diatur secara pasti melalui hukum bahkan bertentangan dengan dasar-dasar hukum yang ada dengan adanya penyimpangan hukum maupun penyeludupan hukum yang terjadi. Salah satunya adalah dengan penerapan perbuatan melawan hukum yang dijadikan dasar gugatan dalam kasus perdata yang membatalkan suatu perjanjian dan diantaranya adalah perjanjian jual beli.

Perbuatan melawan hukum dapat terjadi jika sudah terpenuhinya suatu unsur adanya kesalahan yang merugikan salah satu pihak atau adanya korban, sementara dalam kasus mengenai pembatalan perjanjian, unsur terpenting adalah kontrak itu sendiri. Timbul pertanyaan bahwa apakah perbuatan melawan hukum sudah tepat dijadikan suatu alasan untuk membatalkan perjanjian, padahal jika dilihat dalam unsur-unsurnya lebih tepat untuk menerapkan wanprestasi sebagai dasar gugatan dan untuk pembatalan perjanjian tersebut. Munir Fuady salah satu narasumber yang penulis 
wawancarai berpendapat hal ini terjadi karena para pihak yang menggugat biasanya melihat besar ganti kerugian yang akan diterima, dimana dengan gugatan perbuatan melawan hukum akan ada ganti kerugian materiil dan immateriil, sementara dalam wanprestasi hanya mencakup ganti rugi materiil saja. Penulis bisa memahami keinginan pihak yang dirugikan untuk menginginkan ganti rugi yang sebesar-besarnya, tetapi dengan inilah dapat dilihat adanya kemungkinan celah bagi pihak untuk menuntut meski sebenarnya tidak memenuhi unsur atau syarat untuk membatalkan suatu perjanjian jual beli yang diatur dalan peraturan perundang-undangan yang ada di Indonesia. Meskipun celah ini dapat ditutupi oleh hakim dalam persidangan dengan adanya kewenangan hakim untuk melakukan penemuan hukum dan menciptakan hukum, pada kenyataannya hal ini tidak sesuai dengan hukum yang sudah ada dan menimbulkan ketidakpastian hukum dalam perlindungan hukum itu sendiri. Maka perlindungan hukum bagi para pihak dalam pembatalan perjanjian jual beli akibat perbuatan melawan hukum menjadi terikat erat dengan keputusan dan pertimbangan hakim untuk menentukan apakah suatu perjanjian dapat dibatalkan dan besarnya ganti kerugian yang diterima korban. Padahal hakim juga pada satu sisi tidak boleh campur tangan dalam perjanjian antara para pihak, hanya saja dalam hal-hal seperti ini hakim perlu melaksanakan tugasnya untuk menjunjung tinggi keadilan bagi para pihak apalagi jika posisi para pihak tidak seimbang dimana ada yang lebih lemah.

\section{PENUTUP}

\section{A. Kesimpulan}

Menurut hasil penelitian penulis maka penulis dapat menyimpulkan bahwa hukum di Indonesia telah memberikan perlindungan hukum bagi para pihak jika terjadi suatu pembatalan perjanjian jual beli dan hal ini secara nyata dapat dilihat melalui hukum yang berlaku di Indonesia, baik berupa perundangundangan, yurisprudensi dan secara umum diatur melalui KUH Perdata 
Indonesia. Lalu berkaitan dengan masalah yang timbul mengenai penerapan perbuatan melawan hukum dan penyalahgunaan keadaan itu sendiri, meskipun perbuatan melawan hukum pada umumnya dikaitkan dengan wajibnya ada unsur kesalahan dari salah satu pihak, jika memang terbukti bahwa salah satu pihak dalam perjanjian jual beli melakukan perbuatan melawan hukum, hakim dapat memutuskan untuk membatalkan perjanjian jual beli tersebut dan memberi putusan agar pihak tergugat mengganti kerugian yang diderita oleh korban. Hal ini disebabkan karena penerapan teori ke dalam dunia praktek ternyata ketika sudah dijalani memiliki beberapa perbedaan konsep dan masih banyak hal-hal yang belum diatur secara pasti dalam hukum di Indonesia sehingga menyebabkan hakim pada akhirnya harus mencari hukum dan menciptakan hukum untuk menyeimbangkan posisi antara para pihak dalam suatu perjanjian jual beli yang tidak seimbang dalam kasus-kasus tertentu. Salah satunya ketika gugatan yang digunakan oleh para pihak mengenai pembatalan perjanjian jual beli didasarkan dengan adanya perbuatan melawan hukum, hal ini terjadi karena perjanjian sendiri merupakan hal yang privat antara para pihak yang membuatnya sehingga jika diminta pembatalan oleh salah satu pihak dan memang terbukti adanya unsur kerugian yang diderita serta para pihak dapat membuktikan unsur-unsur pada dasar gugatan tersebut, hakim harus menjunjung tinggi keadilan bagi pihak yang dirugikan itu. Pada akhirnya hakim menerima dasar gugatan perbuatan melawan hukum apabila bisa dibuktikan secara nyata oleh pihak penggugat.

Tetapi meskipun demikian ada beberapa pihak dalam perjanjian yang menggunakan hal ini sebagai celah untuk mendapatkan ganti rugi yang lebih besar meskipun seharusnya dasar gugatan lebih tepat menggunakan wanprestasi ataupun adanya cacat kehendak seperti kesesatan, penipuan, kekhilafan atau cacat kehendak baru berupa penyalahgunaan keadaan yang meski belum diatur secara pasti melalui hukum di Indonesia tetapi sudah dikenal melalui yurisprudensi. Karena pada dasarnya perbuatan melawan hukum bisa 
memberikan ganti rugi dalam bentu materiil dan immateriil, sedangkan yang lain hanya memberikan ganti rugi dalam bentuk materiil. Sehingga hal ini menyebabkan perbuatan melawan hukum menjadi salah satu dasar gugatan untuk membatalkan perjanjian yang lebih dipilih oleh pihak yang bersengketa dan juga perbuatan melawan hukum bisa mencakup tindakan-tindakan yang lebih luas dibandingkan wanprestasi yang lebih mengarah kepada suatu ingkar janji dalam perjanjian. Hukum di Indonesia juga memberikan kewenangan kepada hakim untuk melindungi pihak yang dirugikan jika memang nyata terjadi perbuatan melawan hukum dalam perjanjian jual beli tersebut.

\section{B. Saran}

Meskipun perbuatan melawan hukum bisa digunakan sebagai dasar gugatan untuk membatalkan suatu perjanjian jual beli, sebaiknya hukum di Indonesia sudah dapat diperbaharui dengan merincikan secara lebih mendetail tentang hal-hal yang berkaitan dengan adanya perbuatan melawan hukum dalam suatu perjanjian yang dilakukan salah satu pihak, karena dengan hukum yang ada sekarang, diperlukan hakim yang menentukan apakah tindakan yang dilakukan salah satu pihak sudah cukup bukti untuk dinyatakan sebagai perbuatan melawan hukum. Hal ini tidak efektif dan membuat ketidakpastian karena adanya pilihan dasar gugatan yang belum tentu tepat karena tidak semua pihak dalam perjanjian mengerti benar secara hukum, bisa jadi pihak tersebut hanya mementingkan besarnya ganti rugi yang mungkin diterima dan tidak melihat unsur-unsur lain. Maka penulis memiliki saran agar hukum mengenai pembatalan perjanjian bisa dikembangkan menjadi lebih rinci dan mendetail agar bisa mencakup semua risiko yang mengakibatkan timbulnya pembatalan perjanjian jual beli itu sendiri.

Misalnya dalam kasus yang diangkat penulis, penggugat mendalilkan adanya penyalahgunaan keadaan yang menimbulkan perbuatan melawan hukum, tetapi penyalahgunaan keadaan itu sendiri seharusnya masuk ke dalam cacat kehendak, hanya saja karena belum diatur dalam hukum di Indonesia dan 
yurisprudensi yang berkaitan dengan hal tersebut menyatakan tindakan itu sebagai perbuatan melawan hukum, padahal ada unsur-unsur lain dalam kasus putusan yurisprudensi itu yang menyebabkan timbulnya perbuatan melawan hukum, bukan hanya karena penyalahgunaan keadaan yang berdiri sendiri. Hal yang dapat terjadi jika perbuatan melawan hukum dan wanprestasi sama-sama diterapkan dalam hukum perjanjian atau kontrak maka pada akhirnya nanti di masa mendatang akan timbul berbagai permasalahan yang bisa merugikan para pihak yang memiliki masalah yang berkaitan dengan pembatalan perjanjian jual beli itu sendiri, dimana jika tidak ada kepastian hukum yang berlaku, bisa saja hukum itu sendiri malah disalahgunakan oleh pihak-pihak yang ingin memanfaatkan kondisi tersebut. Salah satunya yang nyata mengenai penyalahgunaan keadaan ini sendiri yang dikaitkan dengan perbuatan melawan hukum, karena belum ada pengertian pasti apa saja yang bisa disebut penyalahgunaan keadaan maka menimbulkan celah bagi pihak-pihak yang ingin mengambil kesempatan tersebut untuk menerapkan dasar gugatan pembatalan perjanjian dengan dasar adanya unsur penyalahgunaan keadaan yang padahal direkayasa sedemikian rupa agar bisa memenuhi unsur yang sebenarnya masih tidak pasti.

Maka penulis berpendapat bahwa hukum di Indonesia sudah perlu mengatur secara khusus pula mengenai penyalahgunaan keadaan agar perlindungan hukum bagi para pihak dalam pembatalan perjanjian bisa lebih terjamin kepastiannya baik dari segi hukum, ganti kerugian maupun penegakannya di kalangan masyarakat, dan akan dapat lebih baik lagi jika wanprestasi bisa dikembangkan agar bisa mencakup hal-hal yang tidak bisa dijangkau hanya dengan hukum yang berlaku sekarang, sehingga adanya pemisahan secara pasti antara perbuatan melawan hukum dengan wanprestasi sehingga lebih menjamin kepastian hukum mengenai perlindungan hukum untuk pembatalan perjanjian jual beli tersebut sendiri. 


\section{DAFTAR PUSTAKA}

\section{A. Buku}

Budiono, Herlien. Ajaran Umum Hukum Perjanjian dan Penerapannya di Bidang Kenotariatan. Cetakan ke-4. (Bandung: PT. Citra Aditya Bakti, 2014).

Dewata, Mukti Fajar Nur dan Yulianto Achmad. Dualisme Penelitian Hukum Normatif \& Empiris. Cetakan ke-4. (Yogyakarta: Pustaka Pelajar 2017).

Fuady, Munir. Perbuatan Melawan Hukum Pendekatan Kontemporer. Cetakan ke-5. (Jakarta: PT. Citra Aditya Bakti, 2017).

H.R., Ridwan. Hukum Administrasi Negara. Cetakan ke-13. (Jakarta: PT. RajaGrafindo Persada, 2017).

Mamudji, Sri. et.al. Metode Penelitian dan Penulisan Hukum. (Jakarta: Badan Penerbit Fakultas Hukum Universitas Indonesia, 2005).

Marzuki, Peter Mahmud. Pengantar Ilmu Hukum. (Jakarta: Prenadamedia Group, 2008).

. Penelitian Hukum Edisi Revisi. Cetakan ke-12. (Jakarta: Prenadamedia Group, 2016).

Nurachmad, M. Buku Pintar Memahami Dan Membuat Surat Perjanjian. Cetakan ke-1. (Jakarta Selatan: Transmedia, 2010).

Saputra, Rendy. Kedudukan Penyalahgunaan Keadaan (Misbruik Van Omstandigheden) Dalam Hukum Perjanjian Indonesia. Cetakan ke-1. (Yogyakarta: Gadjah Mada University Press, 2016).

Soekanto dan Sri Mamudji. Penelitian Hukum Normatif Suatu Tinjauan Singkat. Cetakan ke-17. (Jakarta: PT RajaGrafindo Persada, 2015).

Subekti, R. Hukum Perjanjian. Cetakan ke-13. (Jakarta: PT. Intermasa, 1991). . Aneka Perjanjian. Cetakan ke-9. (Bandung: PT. Citra Aditya Bakti, 1992).

Suharnoko. Hukum Perjanjian Teori dan Analisis Kasus Edisi Kedua Cetakan ke-9. (Jakarta: Prenadamedia Group, 2015).

Yahman. Karakteristik Wanprestasi dan Tindak Pidana Penipuan Yang Lahir Dari Hubungan Kontraktual. Cetakan ke-3. (Jakarta: Prenadamedia Group, 2016). 
Vollmar, H.F.A. Pengantar Studi Hukum Perdata Jilid II. Cetakan ke-1. (Jakarta: Rajawali, 1984).

B. Undang-Undang

Indonesia. Undang-Undang Dasar Negara Republik Indonesia Tahun 1945.

- Kitab Undang-Undang Hukum Perdata. (Burgerlijk Wetboek voor Indonesie).

. Undang-Undang Nomor 48 Tahun 2009 tentang Kekuasaan Kehakiman (Lembaran Negara Republik Indonesia Tahun 2009 Nomor 157, Tambahan Lembaran Negara Republik Indonesia Nomor 5076).

\section{Putusan}

Indonesia. Putusan Pengadilan Negeri Jakarta Selatan Nomor 305/Pdt.G/2014/PN.Jkt.Sel.

Putusan Pengadilan Tinggi Daerah Khusus Ibukota Jakarta Nomor 215/Pdt/2016/PT.DKI.

. Putusan Mahkamah Agung Nomor 523 K/Pdt/2017.

. Putusan Mahkamah Agung Nomor 3641 K/Pdt/2001.

. Putusan Mahkamah Agung Nomor 2356 K/Pdt/2008. 